\title{
THE ANNUAL MEETING OF THE SOCIETY
}

The fifty-second Annual Meeting and twenty-seventh Colloquium of the American Mathematical Society was held at the Museum of Science and Industry, Chicago, Illinois, Friday and Saturday, November 23 and 24, 1945, in conjunction with meetings of the Mathematical Association of America. Over three hundred persons registered, including the following two hundred forty members of the Society:

A. A. Albert, G. E. Albert, N. R. Amundson, T. W. Anderson, K. J. Arnold, Max Astrachan, M. C. Ayer, W. L. Ayres, R. W. Babcock, Reinhold Baer, R. M. Ballard, R. H. Bardell, R. W. Barnard, J. L. Barnes, Walter Bartky, G. E. Bates, J. C. Bell, J. L. Bell, R. F. K. Benton, Lipman Bers, S. F. Bibb, R. H. Bing, K. E. Bisshopp, G. A. Bliss, L. M. Blumenthal, H. F. Bohnenblust, W. M. Borgman, D. G. Bourgin, G. F. Bradfield, C. P. Brady, H. R. Brahana, C. C. Bramble, A. J. Brandt, Richard Brauer, R. H. Bruck, E. L. Buell, R. S. Burington, H. E. Burns, I. W. Burr, L. E. Bush, S. S. Cairns, W. D. Cairns, R. H. Cameron, H. H. Campaigne, W. B. Carver, Subrahmanyan Chandrasekhar, W. F. Cheney, E. W. Chittenden, A. M. Christiansen, R. V. Churchill, Paul Civin, H. M. Clark, E. H. Clarke, C. J. Coe, K. S. Cole, Nancy Cole, B. H. Colvin, J. J. Corliss, Richard Courant, N. A. Court, H. S. M. Coxeter, M. D. Donsker, J. L. Doob, T. L. Downs, W. L. Duren, William H. Durfee, John Dyer-Bennet, Paul Erdös, D. H. Erkiletian, Martinus Esser, H. J. Ettlinger, H. P. Evans, H. S. Everett, I. A. Flodin, L. R. Ford, Tomlinson Fort, J. S. Frame, Evelyn Frank, M. R. Freundlich, A. J. Froseth, B. H. Gere, H. H. Germond, J. W. Givens, A. M. Gleason, L. M. Graves, L. W. Griffiths, V. G. Hachmeister, D. W. Hall, P. R. Halmos, O. H. Hamilton, M. L. Hartung, A. E. Heins, E. D. Hellinger, R. G. Helsel, Fritz Herzog, M. R. Hestenes, E. H. C. Hildebrandt, T. H. Hildebrandt, J. D. Hill, D. L. Holl, M. C. Holland, Carl Holtom, G. B. Huff, R. C. Huffer, S. P. Hughart, H. K. Hughes, Ralph Hull, H. D. Huskey, M. H. Ingraham, R. L. Jeffery, A. W. Jones, B. W. Jones, F. B. Jones, Irving Kaplansky, William Karush, H. P. Kean, D. E. Kearney, A. J. Kempner, R. B. Kershner, Fred Kiokemeister, J. R. Kline, W. C. Krathwohl, Joseph Landin, E. P. Lane, R. E. Langer, G. A. Larew, H. D. Larsen, J. W. Lasley, B. A. Lengyel, Charles Loewner, Z. L. Loflin, A. T. Lonseth, W. C. McDaniel, E. J. McShane, C. C. MacDuffee, Murray Mannos, Morris Marden, J. W. Marshall, Ella Marth, W. T. Martin, J. R. Mayor, Karl Menger, E. J. Mickle, A. N. Milgram, D. D. Miller, H. J. Miser, W. L. Miser, E. J. Moulton, M. E. Munroe, J. R. Musselman, S. B. Myers, J. L. Nagle, C. V. Newsom, K. L. Nielsen, Ivan Niven, E. P. Northrop, F. S. Nowlan, J. M. H. Olmsted, Isaac Opatowski, Philip Peak, P. M. Pepper, L. C. Plant, J. E. Powell, G. B. Price, A. L. Putnam, Tibor Rad6, J. F. Randolph, R. B. Rasmusen, C. H. Rawlins, Mina Rees, W. T. Reid, Haim Reingold, E. K. Ritter, G. de B. Robinson, W. H. Roever, R. E. Root, G. F. Rose, A. E. Ross, J. B. Rosser, Hans Samelson, R. G. Sanger, J. B. Scarborough, A. T. Schafer, R. D. Schafer, O. F. G. Schilling, J. E. Schubert, G. E. Schweigert, M. E. Shanks, Seymour Sherman, D. M. Smiley, M. F. Smiley, C. V. L. Smith, G. W. Smith, H. L. Smith, R. D. Specht, Abraham Spitzbart, C. E. Springer, M. P. Steele, N. E. Steenrod, R. C. Stephens, B. M. Stewart, C. N. Stokes, M. H. Stone, R. G. Stoneham, E. B. Stouffer, W. T. Stratton, 
J. S. Stubbe, R. L. Swain, J. L. Synge, H. P. Thielman, J. M. Thomas, W. R. Transue, E. F. Trombley, H. F. Tuan, A. W. Tucker, H. L. Turrittin, S. M. Ulam, E. H. Umberger, E. P. Vance, G. B. Van Schaack, J. I. Vass, M. F. Vaudreuil, H. E. Vaughan, S. E. Warschawski, C. P. Wells, E. T. Welmers, M. E. Wescott, P. M. Whitman, W. M. Whyburn, L. R. Wilcox, R. L. Wilder, F. B. Wiley, R. B. Wiley, S. S. Wilks, R. S. Wolfe, M. A. Wurster, G. S. Young, J. W. T. Youngs, Daniel Zelinsky, J. W. Zimmer.

The twenty-seventh Colloquium consisted of four lectures on Length and area by Professor Tibor Radó of Ohio State University. The lectures took place at 9:30 A.M. and 2:00 P.M. on Friday and on Saturday, and were presided over by Professors J. M. Thomas, C. C. MacDuffee, President T. H. Hildebrandt and Secretary J. R. Kline.

Sessions for the reading of short papers were held Friday at 10:45 A.M. and 3:15 P.M. and Saturday at 3:15 P.M. Presiding officers for these sessions were Professors A. A. Albert, L. M. Graves and W. L. Ayres.

The nineteenth Josiah Willard Gibbs Lecture was delivered by Professor J. C. Slater of the Massachusetts Institute of Technology on Friday evening at 7:30 P.M., with President T. H. Hildebrandt presiding. The title of Professor Slater's address was Physics and the wave equation. About three hundred people attended.

The annual business meeting and election of officers was held on Saturday morning, President T. H. Hildebrandt presiding. Dean Tomlinson Fort of Lehigh University presented resolutions expressing the thanks and appreciation of the members of the Society and the Association to the officials of the Museum of Science and Industry and to the local committee for the excellent arrangements. Further proceedings are included later in the report.

At 11:00 A.M. Saturday, following Professor Rado's third lecture, Professor S. M. Ulam of the University of Southern California presented an address entitled On the stability of functional equations. Professor R. E. Langer presided.

Sessions of the Mathematical Association of America were held on Saturday evening and Sunday morning.

At the meeting of the Board of Trustees at 6:00 P.M., November 23, 1945, in the Hotel Windermere East, there was no quorum present and the Board adjourned to January 4, 1946. The Council met at 9:00 P.M. on November 23, 1945, in the Hotel Windermere East.

The Secretary announced the election of the following seventeen persons to ordinary membership in the Society: 
Mr. Arthur Bernstein, Carnegie Institution of Washington;

Miss Nancy Brixey, Davis and Gilbert, New York, N. Y.;

Mr. Willie Russell Callahan, Department of Electrical Engineering, Yale University; Professor Clarence Selmer Carlson, St. Olaf College;

Mr. Kenneth Collwell Cartwright, P.P.G. Co., Barberton, Ohio;

Mr. Peter Jennings Gill, Magnetic Observatory, Christchurch, New Zealand;

Mr. Frank Harary, New York University;

Mr. J. Halcombe Laning, Jr., Watertown Arsenal, Watertown, Mass.;

Professor Harvey M. Lashier, Pacific Union College, Angwin, Calif.;

Mr. John H. Lewis, N.D.R.C., New York, N. Y.;

Mr. Jesse Eugene Sherwood, N.D.R.C., Cumberland, Md.;

Professor Yu-Why Tschen, National University of Peking, Peking, China;

Mr. Edmund Forrest Tyler, Los Angeles, Calif.;

Mr. Stephen Eugene Walkley, U.S.N.R.;

Dr. Everett C. Westerfield, Costa Mesa, Calif.;

Professor L. C. Young, University of South Africa, Capetown;

Mr. John Anthony Zulon, U.S.A.

The following appointments by President T. H. Hildebrandt were reported: as representative of the Society at the Seventy-fifth Anniversary of Wilson College on October 13, 1945, Professor F. W. Owens; as representative of the Society at the inauguration of William Allison Shimer as President of Marietta College on October 20, 1945, Professor J. L. Synge; as representative of the Society at the inauguration of George Henry Armacost as President of the University of Redlands on November 4, 1945, Professor Morgan Ward; as representative of the Society at the inauguration of Howard S. McDonald as President of Brigham Young University on November 14, 1945, Professor M. T. Bird; as representative of the Society at the inauguration of Franklin Stewart Harris as President of Utah State Agricultural College on November 16, 1945, Professor I. O. Horsfall; as a Committee on Arrangements for the 1945 Annual Meeting in Chicago, Illinois, Dean R. G. Sanger (Chairman), Professors R. H. Bruck, B. W. Jones, W. T. Reid, and L. R. Wilcox; as tellers for the election at the 1945 Annual Meeting, Professor W. C. Krathwohl, Drs. Mary E. Ladue and W. C. Strodt; as a committee to study the implementation of the Birkhoff Memorial Committee report, Professors M. H. Stone (Chairman), R. M. Foster, and R. E. Langer; as a Committee on the Award of the Cole Prize in Theory of Numbers, to be awarded at the 1946 Annual Meeting for papers published during the period 1941-1945, Professors E. T. Bell (Chairman), Emil Artin, and H, W. Brinkmann; as Chairman of the Committee on Visiting Lectureships, term to expire December 31, 1947, Professor Hassler Whitney; as a member of the Committee on Visiting Lectureships, Professor Norbert Wiener. (Professor 
Wiener was reappointed for a period of three years, 1946-48; committee now consists of Professor Hassler Whitney, Chairman, Dean R. G. D. Richardson, and Professor Wiener.)

At the annual election which closed on November 24, and at which 544 votes were cast, the following officers were elected:

Vice Presidents, Professors L. R. Ford and Saunders MacLane.

Associate Secretaries, Professors W. L. Ayres, R. H. Bruck and A. C. Schaeffer.

Member of the Editorial Committee of the Bulletin, Professor Deane Montgomery.

Member of the Editorial Committee of the Transactions, Professor A. A. Albert.

Member of the Editorial Committee of the Colloquium Publications, Professor J. F. Ritt.

Member of the Editorial Committee of Mathematical Reviews, Professor O. E. Neugebauer.

Member of the Editorial Committee of Mathematical Surveys, Professor A. W. Tucker.

Member of the Editorial Committee of the American Journal of Mathematics, Professor L. M. Graves.

Members at large of the Council, Dr. R. P. Boas, Professors R. H. Cameron, R. V. Churchill, Churchill Eisenhart, and A. P. Morse.

Professor M. H. Stone was elected by the Council as a member of the Editorial Committee of Mathematical Reviews to fill the unexpired term of Professor J. D. Tamarkin.

It was reported that Professor Marston Morse had been selected to act as Chairman of the Emergency Committee of the International Congress of Mathematicians.

It was reported that Professor Subrahmanyan Chandrasekhar had accepted the invitation to deliver the twentieth Josiah Willard Gibbs Lecture at the 1946 Annual Meeting and that Professor Oscar Zariski had accepted the invitation to deliver a series of Colloquium Lectures at the 1947 Summer Meeting on the subject Abstract algebraic geometry.

The Secretary reported that he had submitted to the Rockefeller Foundation a report on the activities of the War Policy Committee for the period August 1, 1944-September 30, 1945.

Certain invitations to give addresses were announced: Professor A. D. Wallace for the February, 1946, meeting in New York City; Professor O. F. G. Schilling for the April, 1946, meeting in Chicago; Dr. P. F. Reichelderfer for the November, 1946, meeting in the mid- 
west; Professor N. E. Steenrod for the April, 1947, meeting in the midwest.

The Secretary reported the completion of the biennial membership campaign held during the latter part of October when approximately 3,200 college teachers of mathematics, including 950 members of the Mathematical Association of America, were invited to membership in the Society. The Secretary is pleased to report at this time that the ordinary membership in the Society is now 2828, including 210 nominees of institutional members and 63 life members. There are also 87 institutional members. The total attendance at all meetings in 1945 was 628 ; the number of papers read was 196; there were 5 hour addresses, 5 symposium addresses, 1 Gibbs Lecture, and four Colloquium Lectures; the number of members attending at least one meeting was 570 .

The Council adopted the following resolution on the death of Professor J. D. Tamarkin:

On November 18, 1945, this Society lost one of its most active and beloved members through the untimely death of Jacob David Tamarkin in his fifty-eighth year of life. His health had been failing for some time, but we had hoped that he would recover his strength and usefulness which was more than life itself to him.

J. D. was the friend of us all and of mathematicians all over the world for whom he kept open house. He was intensely human, generous, gregarious, and warmhearted; he loved music, a good table and a friendly chat. He took an active interest in his many friends, their personal problems, and their scientific work and gave his time and counsel without stint. His hearty laughter and booming voice brought cheer wherever he went.

He came as a stranger to our shores two decades ago but soon found an active place in American mathematical life to the development of which he was to contribute so much. He read widely and with passion and many of us have profited from his constructive criticism and advice. His critical ability was soon discovered and utilized: he served on the Editorial Committees of the Transactions, the Colloquium, the Mathematical Reviews, and the Mathematical Surveys. He was a member of the Council since 1931 and a Vice President in 1942-1943.

His intellectual honesty, high standards, and civil courage made themselves felt everywhere. He helped materially in placing Brown University in the mathematical front rank and his editorial activities during a critical time were a driving force in the growth and development of mathematical research in this country. He saw the problems of the Society clearly and in their proper perspective and fought fearlessly for his convictions. His vigorous personality never became overbearing, he fought well but also cleanly. To his many collaborators and students he was a source of ideas, information, and inspiration, a friendly guide and critic, and his influence on their mathematical development was profound. His own contributions to classical as well as modern functional analysis were many and of lasting value.

The Council of the American Mathematical Society voices its deep sense of loss in the decease of J. D. Tamarkin. He lives in his work and in our fond memories.

This resolution was read at the annual business meeting and the 
members of the Society stood for a minute in respect to the memory of their distinguished colleague.

On recommendation of the Committee on Places of Meetings, the Council voted to accept the invitation of Cornell University to hold the 1946 Summer Meeting at that institution at a date to be decided.

Since the 1945 Annual Meeting was held before the close of the Society's fiscal year, it was impossible to present a full report of the Treasurer. (Excerpts of the final report of the Treasurer, however, appear on pages 44-47 of this Bulletin.) It was reported that the Society's finances were in excellent shape, that the net excess of receipts over disbursements for the year would be somewhat more than $\$ 10,000$. The Society's investment portfolio now includes government bonds 27 per cent, other bonds 18 per cent, preferred stocks 13 per cent, common stock 35 per cent, cash in banks 7 per cent, and total assets amount to approximately $\$ 270,000$. During the year the Trustees directed the transfer to the Endowment Fund Principal from surplus of a sufficient amount to bring the principal to $\$ 71,000$, slightly more than its value before the charges for depreciation of securities were made in 1940 . While there is a considerable surplus, this is desirable because we shall soon be faced with a large volume of publication at considerably increased costs.

The Librarian reported the following additions to the Library: 29 books, 89 bound volumes of periodicals, 162 pamphlets (most of them are printed dissertations), and 229 dissertations on microfilm. $\mathrm{He}$ also reported that the use of the library had been twice as great during 1944-1945 as in 1943-1944. A great deal of work has been done during the past year by the staff of the New York office and by a special assistant on the revision of the Catalogue of the Library. A new edition of this Catalogue will be published and distributed to members of the Society early in 1946. The Librarian is establishing archives of the Society for the preservation of letters and documents of importance. Members are invited to send to the Librarian documents in their possession which may be placed in the archives.

The Bulletin Editorial Committee reported that it would publish slightly under 1,000 pages in 1945. It was reported that Professors E. G. Begle and Otto Szász had been appointed as Assistant Editors, to replace Professors J. H. Curtiss and D. H. Lehmer.

The Transactions Editorial Committee reported that it would publish 965 pages during 1945. During the past year Professor Oscar Zariski has been on leave of absence from his university for scientific work in Brazil. His duties in connection with the Transactions have been carried on by Professor R. L. Wilder. Professor Oystein Ore 
will retire as an Associate Editor and will be replaced by Professor O. F. G. Schilling. The backlog of papers is about the same as last year but there is some expectation that a large number of new manuscripts will be submitted in the near future.

The Mathematical Reviews Editorial Committee reported that during the latter part of 1945 the size of the issue was increased from 28 to the original 32 pages and it is expected that this increase in size will be the minimum increase in 1946. The gaps in the foreign literature are being filled although there are still quite a few remaining, particularly in the Italian literature. In 1945 Mathematical Reviews obtained the sponsorship of the Institute of Mathematical Statistics. The subscription list contains 1,382 names. This is a remarkable record when one considers the fact that most foreign mathematicians have been unable to subscribe during this period.

The Council appointed Professors K. O. Friedrichs, Norman Levinson, and R. L. Wilder as representatives of the Society on the Editorial Board of the Annals of Mathematics for a period of three years beginning 1946

The Council voted to continue for another year the plan of reduced dues to members of the Society who are serving as enlisted men in the armed forces of the United States and Canada. Application for this privilege must be made in accordance with instructions which are mailed to members with annual bills on January 1.

The Council approved a plan, submitted by President Hildebrandt and Secretary Kline, for establishing a Policy Committee for Mathematics, and adopted procedures for the election of the representatives of the American Mathematical Society on this committee.

Titles and cross references to papers read at the meeting follow below. Papers 1 to 5 and paper 34 were read Friday morning. Papers 6 to 12 were read Friday afternoon. Papers 13, 14, 16, 17, 19, 43 and 44 were read Saturday afternoon. Except as noted above, papers 15 through 45 were read by title; their abstract numbers are followed by the letter $t$. Paper 7 was read by Professor Cameron, 8 by Dr. Kaplansky, 11 by Professor Bers, 17 by Professor Samelson, 43 by Professor Heins and 44 by Professor Herzog. Professor Schiffer was introduced by Dr. Stefan Bergman.

1. B. W. Jones: Equivalence of quadratic forms over the ring of 2-adic integers. (Abstract 52-1-3.)

2. H. S. M. Coxeter: The Petrie polygon of a regular solid. (Abstract 51-11-235.)

3. Richard Brauer: On the arithmetic in a group ring. II. Preliminary report. (Abstract 52-1-1.) 
4. Ivan Niven: Sums of squares of integral quaternions. (Abstract 51-1-5.)

5. G. B. Huff: Inequalities connecting solutions of Cremona's equations. (Abstract 52-1-34.)

6. S. E. Warschawski: On the modulus of continuity of the mapping function at the boundary in conformal mapping. (Abstract 52-1-25.)

7. R. H. Cameron and W. T. Martin: The orthogonal development of nonlinear functionals in series of Fourier-Hermite functionals. (Abstract 52-1-15.)

8. Paul Erdös and Irving Kaplansky: The asymptotic number of Latin rectangles. (Abstract 52-1-2.)

9. Paul Civin: Fourier coefficients of dominant functions. (Abstract 51-11-212.)

10. R. H. Bing: Solution of a problem of J. R. Kline. (Abstract 52-1-46.)

11. Lipman Bers and Abe Gelbart: $A$ topological property of solutions of partial differential equations. (Abstract 52-1-12.)

12. F. B. Jones: Concerning the separability of certain locally connected metric spaces. (Abstract 52-1-48.)

13. Isaac Opatowski: Markoff chains and Tchebychev polynomials. (Abstract 52-1-44.)

14. P. R. Halmos: The theory of unbiased estimation. (Abstract 52-1-43.)

15. Lipman Bers and Abe Gelbart: A remark on the LebesgueSperner covering theorem. (Abstract 52-1-45-t.)

16. S. B. Myers: Equicontinuous sets of mappings. (Abstract 52-1-50.)

17. Deane Montgomery and Hans Samelson: Fiberings with singularities. (Abstract 51-11-251.)

18. J. L. Kelley and Everett Pitcher: Applications of natural homomorphism sequences. (Abstract 52-1-49-t.)

19. Charles Loewner: On pairs of quadratic forms in Hilbert space. (Abstract 52-1-19.)

20. Richard Brauer: On the representation of a group of order $g$ in the field of the gth roots of unity. (Abstract 51-11-201-t.)

21. S. A. Kiss: Transformations on lattices and structures of logic. (Abstract 52-1-4-t.)

22. A. R. Schweitzer: On the genesis of number systems. I. (Abstract 52-1-39-t.)

23. A. R. Schweitzer: On the genesis of number systems. II. (Abstract 52-1-40-t.)

24. D. G. Bourgin: Quadratic forms. (Abstract 51-11-246-t.) 
25. R. P. Agnew: $A$ simple sufficient condition that a method of summability be stronger than convergence. (Abstract 51-11-208-t.)

26. J. W. T. Youngs: Various definitions of surface and area. Preliminary report. (Abstract 52-1-26-t.)

27. Mark Kac: Distribution of eigenvalues of certain integral equations with an application to roots of Bessel functions. Preliminary report. (Abstract 52-1-18-t.)

28. C. F. Stephens: Solutions of systems of nonlinear difference equations in the neighborhood of a singular point. (Abstract 52-1-24-t.)

29. D. G. Bourgin: Complete sets of functions. (Abstract 52-1-14-t.)

30. N. R. Amundson: On the boundary value problem of third kind for the quasi-linear parabolic differential equation. (Abstract 52-1-9-t.)

31. D. G. Bourgin: A class of generating functions. (Abstract 52-1-13-t.)

32. H. S. M. Coxeter: The order of the symmetry group of the general regular hyper-solid. (Abstract 51-11-234-t.)

33. L. M. Blumenthal: Metric characterization of elliptic space. (Abstract 52-1-31-t.)

34. C. E. Springer: Rectilinear congruences whose developables intersect a surface in its lines of curvature. (Abstract 52-1-36.)

35. Edward Kasner and John DeCicco: Heat surfaces. (Abstract 52-1-27-t.)

36. John DeCicco: Differential geometry in the Kasner plane. (Abstract 52-1-33-t.)

37. J. L. Doob: Markoff chains-denumerable case. (Abstract 51-11-242-t.)

38. Isaac Opatowski: Calculation of. Markoff chains by incomplete gamma and beta functions and by Charlier polynomials. (Abstract 51-11-244-t.)

39. Will Feller: On the normal approximation to the binomial. (Abstract 52-1-42-t.)

40. Will Feller: Note on the law of large numbers and "fair" games. (Abstract 52-1-41-t.)

41. Menahem Schiffer: Hadamard's formula and variation of domain-functions. (Abstract 52-1-23-t.)

42. S. C. Chang: $A$ new foundation of the projective differential theory of curves in five-dimensional space. (Abstract 52-1-32-t.)

43. A. E. Heins and Norbert Wiener: $A$ generalization of the Wiener-Hopf integral equation. (Abstract 52-1-17.)

44. Fritz Herzog and J. D. Hill: The Bernstein polynomials for discontinuous functions. (Abstract 51-7-115.)

45. Gordon Pall: On generalized quaternions. (Abstract 52-1-6-t.)

R. H. BRUCK, Associate Secretary 


\section{APPENDIX}

\section{EXCERPTS FROM REPORT OF TREASURER}

December 18,1945

To THE Board OF Trustees of the American Mathematical Society

\section{Gentlemen:}

I have the honor to submit herewith the report of the Treasurer for the fiscal year ended November 30,1945 . The following comments may be of interest.

\section{Investment Portfolio}

On November 30, 1945, the market value of securities held for Invested Funds exceeded book value by $\$ 26,930$, and the market value of securities held for Current Funds exceeded book value by $\$ 1,863$, thus reflecting the recent rise in security prices. In view of these figures and of the conservative character of many of the securities, the reserves held in accounts "Reserve for Investment Losses" and "Profit on Sales of Securities" are adequate protection against contingent depreciation in market value.

The size of the investment portfolio suggests that it may be helpful to include here a summary of the changes in security holdings made on authorization of the Board of Trustees during the year. I need hardly remind you in this connection of the value to the Society of the services of the City Bank Farmers Trust Company as Custodian.

Acquired by Purchase:

50 shares Crane Co. Cum. Pfd. $3 \frac{3}{4}$

25 shares Union Carbide and Carbon Cap.

200 shares National Dairy Products Com.

$\$ 5,000 \quad$ New York, Chicago and St. Louis RR. Ref. 3 $\frac{3}{4} 1975$

$\$ 5,000 \quad$ U. S. Treasury $2 \frac{1}{2} 1972-67$

$\$ 5,200 \quad$ U. S. Savings Ser. G Ref. $2 \frac{1}{2} 1957$

Acquired as Gift:

$\$ 25$ U. S. Savings Ser. F. 1957

Acquired through Exchange:

50 shares Tidewater Associated Oil Co. Cum. Pfd. $4 \frac{1}{2}$ for 50 shares Tidewater Associated Oil Co. Cum. Pfd. $3 \frac{3}{4}$

200 shares Sears Roebuck and Co. Com. for 50 shares, in stock split. 
Called:

50 shares Crane Co. Cum. Pfd. 5

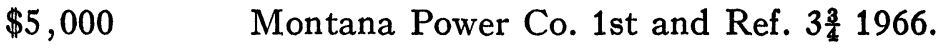

The investment portfolio, valued at market November 30, 1945, now includes Government bonds 28 per cent, other bonds 16 per cent, preferred stock 13 per cent, common stock 37 per cent, cash in savings banks 6 per cent.

\section{Income from Investments}

Income received during the year from investment of Current Funds amounted to $\$ 1,245$, exclusive of $\$ 98$ earmarked for International Congress. This represents a return of something less than 2.1 per cent computed on average book value of investments. Income on Invested Funds amounted to $\$ 7,367$, representing a return of approximately 3.8 per cent. Total investment income from all sources was thus $\$ 8,710$, representing a return somewhat under 3.37 per cent. This rate of return is very slightly over the corresponding rate for the fiscal year 1944, increased common stock dividend payments having been more than sufficient to offset lower yields from fixed income securities.

Income from the Henderson Estate was $\$ 4,750$, which is $\$ 239$ more than was received in 1944 from this source.

\section{Increase in Surplus and Assets}

Surplus account shows an increase of $\$ 4,637$ after transferring $\$ 5,427$ from Surplus to Endowment Fund Principal, and after setting up a reserve of $\$ 2,500$ for payment for the Library Catalogue. The transfer to the Endowment Fund brought the principal to $\$ 71,000$, slightly more than its value before the charges for depreciation of securities were made in 1940 . The increase in Surplus is about one-half of the corresponding figure for the preceding year. It is to be expected that costs will increase in the next fiscal year when, in addition to the Library Catalogue and the biennial List of Members, at least two Colloquium volumes will be printed and one reprinted.

The net increase in assets for the year amounted to nearly $\$ 14,500$.

Respectfully submitted, Bennington P. Gill, 
BALANCE SHEET

Assets

CURRENT FUNDS:

November November

$30,1945 \quad 30,1944$

Cash.

$\$ 24,868.41$

Investments $54,433.13$

$27,973.79$ $41,839.37$

$\$ 79,301.54$

$\$ 69,813.16$

INVESTED FUNDS:

Cash. .

$\$ 5,833.06$

Investment $187,543.57$

$\$ 193,376.63$

$\$ 272,678.17$

Total Assets.

$\$ \quad 336.09$ $188,059.77$

$\$ 188,395.86$

$\$ 258,209.02$

CurRent Funds:

\section{Liabilities}

Mathematical Reviews..................

Colloquium..........................

$\$ 13,637.34$

$9,310.80$

Mathematical Surveys....................

$1,250.95$

Library Catalogue.

$1,868.68$

Reprinting Funds.................. 3,310.24

Prize Funds and Other Special Funds

Accumulated Income.................

International Congress...................

War Policy Committee. ...................

$4,518.11$

$6,331.71$

143.25

Sinking Fund

820.91

413.36

Profit on Sales of Securities. . . . . . . . . . . .

Miscellaneous.

91.60

Surplus. .

$37,604.59$

$\$ 79,301.54$

$\$ 11,936.09$

$7,368.15$

$1,236.10$

$3,765.26$

$3,332.75$

$6,233.39$

$1,719.41$

768.96

413.36

72.56

$32,967.13$

$\$ 69,813.16$

\section{INVESTED FUNDS:}

Endowment Fund Principal

$\$ 71,000.00$

$31,033.22$

Prize Funds and Other Special Funds.

$3,866.88$

Life Membership and Subscription Reserve......

Colloquium

$5,000.00$

$65,000.00$

$4,385.89$

$\$ 65,573.18$

$31,033.22$

$4,032.68$

$5,000.00$

$65,000.00$

Reserve for Investment Losses... . . . . . . . . . . .

Profit on Sales of Securities.

$13,090.64$

$4,385.89$

$13,370.89$

$\$ 193,376.63$

$\$ 188,395.86$

Total Liabilities

$\$ 272,678.17$

$\$ 258,209.02$ 


\section{SUMMARY STATEMENT OF INCOME AND EXPENDITURES \\ 1944-1945}

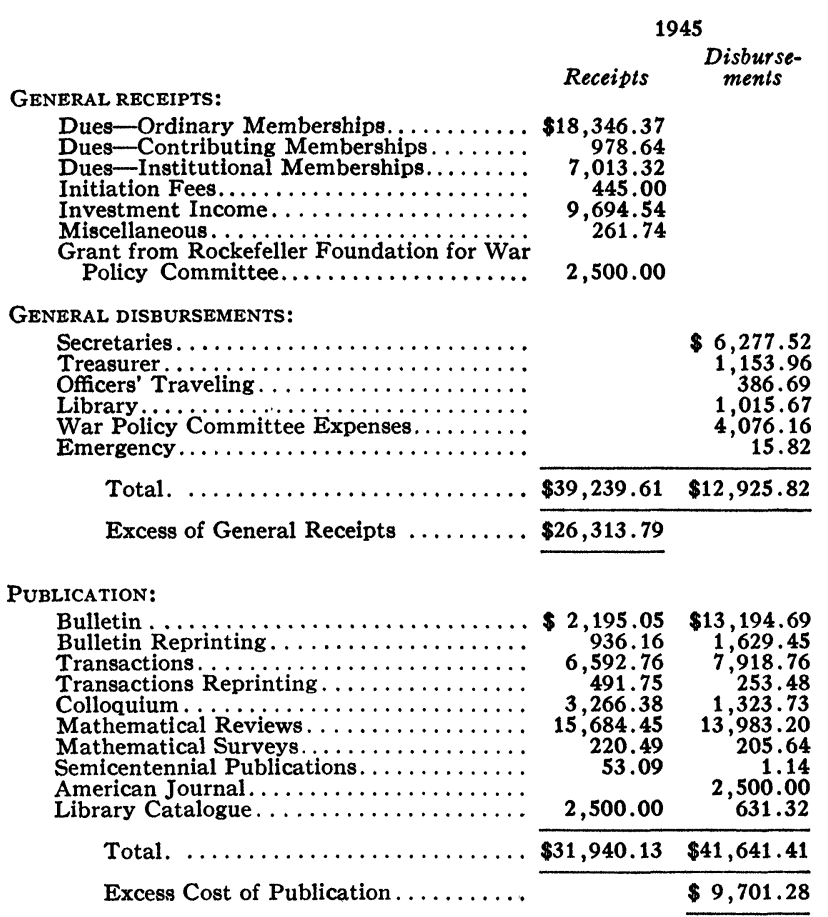

\section{OTHER:}

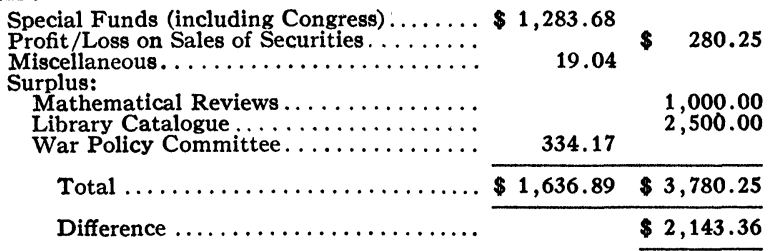

Net Change in Assets.

$\$ 14,469.15$

$\$ 258,209.02$

ASSETS BEGINNING OF YEAR

ASSETS END OF YEAR $\ldots \ldots \ldots \ldots \ldots \ldots$
1944 Receipts $\begin{gathered}\text { Disburse- } \\ \text { ments }\end{gathered}$

$$
\begin{array}{r}
\$ 18,060.64 \\
948.06 \\
7,510.02 \\
793.95 \\
8,836.16 \\
353.84 \\
3,750.00
\end{array}
$$

\begin{tabular}{rr} 
& $5,642.71$ \\
$1,070.77$ \\
600.00 \\
984.46 \\
$2,030.59$ \\
158.38 \\
\hline$\$ 40,252.67 \quad \$ 10,486.91$ \\
\hline$\$ 29,765.76$
\end{tabular}

$\$ 2,462.10 \$ 11,189.68$ 856.40 $7,097.63 \quad 8,644.20$ 669.76

$3,210.08 \quad 1,603.62$ , $753.49 \quad 12,770.02$ $713.82 \quad 317.75$ $180.65 \quad 4.03$ $2,500.00$

$\$ 30,643.93 \quad \$ 37,029.30$

$\$ 6,385.37$

$\$ 1,223.90 \$ 100.00$ 141.03

$\$ 1,364.93 \$ 1,108.43$

256.50

$\$ 23,636.89$

$\$ 234,572.13$ 